International Research Journal of Management, IT \& Social Sciences
Available online at https://sloap.org/journals/index.php/irjmis/
Vol. 7 No. 1, January 2020, pages: 84-94
ISSN: 2395-7492
https://doi.org/10.21744/irjmis.v7n1.824

\title{
Fraud Pentagon Theory in Detecting Financial Perception of Financial Reporting with Good Corporate Governance as Moderator Variable
}

I Gusti Ngurah Hiwa Sawaka K. I Wayan Ramantha

Article history:

Submitted: 18 November 2019

Revised: 27 December 2019

Accepted: 03 January 2020

\section{Keywords:}

financial reporting; fraud pentagon theory; good corporate governance; moderator variable; perceptions of fraudulent;

\begin{abstract}
This study aims to provide empirical evidence about fraud pentagon theory in detecting perceptions of fraud with good corporate governance as moderating. The study was conducted at all PT BPRs in Bali Province who held positions as directors and commissioners. The sampling technique uses saturated samples and uses the Yamane formula and produces 225 samples that are worthy of study. The data analysis technique used in moderated regression analysis. The test results found that the pentagon theory fraud indicator namely pressure negatively affects the perception of fraudulent financial reporting. Opportunities and rationality have a positive effect on perceptions of financial reporting fraud. Competence and arrogance do not affect the perception of financial reporting fraud. GCG weakens the negative effect of pressure on perceptions of fraudulent financial reporting. GCG weakens the positive influence of opportunity and rationality on the perception of fraud. GCG does not moderate the effect of competence and arrogance on perceptions of fraudulent financial reporting, but GCG is a type of potential moderation for the interaction of competence and arrogance.
\end{abstract}

International research journal of management, IT and social sciences (C) 2020. This is an open access article under the CC BY-NC-ND license (https://creativecommons.org/licenses/by-nc-nd/4.0/).

\section{Corresponding author:}

I Gusti Ngurah Hiwa Sawaka K.,

Faculty of Economics and Business, Udayana University, Denpasar, Indonesia.

Email address: hiwasaka274@yahoo.com

Udayana University, Denpasar, Indonesia

Udayana University, Denpasar, Indonesia 


\section{Introduction}

Meckling \& Jensen (1976), explains that agency theory is a theory that explains the relationship that occurs between principal and agent. The theory occurs because there are differences in interests between agents and principals. The differences in interests that occur make selfish qualities emerge in the agent (Einshardt, 1989). Perception of fraudulent financial reporting is one of the traits that will occur due to self-interest. ACFE Asia Pacific in 2018 explained that Indonesia was ranked 3rd of fraud in the Asia Pacific region and financial reporting fraud was one of the three most harmful types of fraud (ACFE, 2018). Cressey (1953), explains that fraud occurs as a result of pressure, opportunity, and rationality (fraud triangle theory). Horwarth (2011), then developed the theory and added 2 elements namely arrogance and competence. Empirical evidence has also been proven by several previous researchers who explain that pressure, opportunity, rationalization, competence, and arrogance have a positive effect on financial reporting fraud (Junardi et al. 2018; Tessa \& Harto, 2016; Oka et al. 2018; Aprilla et al. 2018; Kusuma et al. 2017; and Puspitha \& Yasa, 2018). Inconsistent with research conducted by Setiawati \& Baningrum (2018); Kurnia \& Anis (2017); Rengganis et al. (2019); Pamungkas et al. (2018); Septiarini \& Handayani (2018); Husmawati et al. (2017); and Danuta (2017), in explaining the influence of pressures, opportunities, rationalization, competence and arrogance on financial reporting fraud.

Self-interest that occurs in the agent can be minimized by issuing costs that are agency costs so that the agent can work in accordance with the interests of the principal. Meckling \& Jensen (1976), explained that there are 3 types of agency costs that need to be spent by principals so that their interests can be in accordance with the interests of agents, namely 1) supervision costs 2) bonding costs and 3) residual loss. Frauds that occur and additional costs incurred can be detrimental to the principal so that GCG can be applied consistently to minimize this. Based on POJK number 4 / POJK.03 / 2015 article 2 (2) one of the reasons for applying GCG is to handle conflicts of interest that occur in rural banks. Empirically, it has also been proven by Aprilia (2017), who conducted research on all ASEAN companies implementing the ASEAN CG scorecard. The results showed that the five proxies in pentagon fraud on average had no significant effect on fraudulent financial reporting. The researcher concluded that the study sample was a company that had obtained the ASEAN CG Scorecard certificate, which company had been proven to run GCG well, so there was minimal fraud. In'airat (2015), conducted on all companies listed on the Saudi Arabian stock market shows that corporate governance variables can reduce the level of fraud. The multiple regression analysis tests show that an internal audit (a proxy of GCG) plays a major role in reducing the level of fraud. But there needs to be existence, existence and consistent effectiveness in a company so that the implementation of governance is able to reduce fraud.

\section{Literature Review and Hypotheses Development}

Previous research explains theoretically that individuals in fulfilling their personal interests will commit fraud to get out of this pressure zone, for example, the pressure to achieve financial targets (Akbar, 2017 \& Rukmana, 2018). Research conducted by Oka et al. (2018), also found that pressures with a proxy for external pressures had a positive effect on fraudulent financial reporting. The conclusion is theoretically that individuals can achieve bonuses and high income can be achieved if they have maximum performance. The maximum performance here can be achieved by opportunistic actions namely financial reporting fraud. The results of the study are similar to those of Quraini \& Rimawati (2018); Rukmana (2018) and Rengganis et al. (2019), who state that there is a positive influence on financial reporting fraud.

H1: Pressure has a positive effect on perceptions of fraudulent financial reporting

Research conducted by Kusuma et al. (2017); and Rukmana (2018), found a positive influence on opportunities for fraudulent financial reporting. The conclusion is theoretically to fulfill his personal interests, individuals will have the perception of cheating if they have the opportunity or when there is weak supervision in an organization/company. Muhsin \& Nurkhin (2018), also explained that a large opportunity will make individuals inclined to commit fraud. The hypothesis that can be described based on the above explanation is as follows:

H2: Opportunity has a positive effect on perceptions of fraudulent financial reporting

Empirical evidence found by Oka et al. (2018); Aprilla et al. (2018); Sanjaya \& Dwirandra (2019); and Siddiq (2017), found that rationalization was proxied by auditor changes and measured by dummy variables had a positive effect on fraudulent financial reporting. Previous researchers explained that the change of auditor can be considered to eliminate traces of fraud found by the previous auditor. The tendency is to encourage companies to replace their independent

Sawaka K., I. G. N. H., \& Ramantha, I. W. (2020). Fraud pentagon theory in detecting financial perception of financial reporting with good corporate governance as moderator variable. International Research Journal of Management, IT and Social Sciences, 7(1), 84-94. https://doi.org/10.21744/irjmis.v7n1.824 
auditors to cover up the fraud contained in the company. Theoretically, it can be concluded that in order to fulfill individual interests, rationalization is done to cover up the perception of fraud that will be done so that the individual can avoid the risk of fraud. The hypothesis that can be described based on the above explanation is as follows:

H3: Rationalization has a positive effect on perceptions of financial reporting deficiencies

Research conducted by Aprilla et al. (2018); Puspitha \& Yasa (2018); and Zamzam et al. (2017), found that competence which is proxied by director changes and measured by dummy variables has a positive effect on fraudulent financial reporting. Wolfe \& Hermanson (2004), also suggested that changes in directors were able to cause a stress period that resulted in more opportunities for fraud perception. The conclusion is someone's position in the organization can provide the ability to create or take advantage of opportunities to commit fraud. Theoretically, it can also be explained that the ability to commit fraud is caused by an interest in oneself to gain a lot of benefits for oneself (selfinterest). The hypothesis that can be described based on the above explanation is as follows:

H4: Competence has a positive effect on perceptions of financial reporting fraud

Research conducted by Tessa \& Harto (2016); Bawekes et al. (2018); Pramana et al. (2019); and Puspitha \& Yasa (2018), found that arrogance with a proxy for the number of CEO photos in the annual report had a positive effect on fraudulent financial reporting. The researchers explained that a CEO or board of directors who had quite a lot of pictures in the company's annual report judged that the CEO had a desire to be known by the public at large. Theoretically, it can be concluded that this trait arises because of the large self-interest (self-interest) that makes the arrogance even greater. This trait will trigger the belief that he will not be known if the fraud has occurred and the existing sanctions do not apply to him. The hypothesis that can be described based on the above explanation is as follows:

H5: Arrogance has a positive effect on perceptions of fraudulent financial reporting

Inconsistencies that occur in previous studies encourage researchers to enter the moderating variable, namely good corporate governance. The researcher suspects that there are variables that interact with the influence of pressure on the perception of fraudulent financial reporting. Jensen \& Meckling (1976), explained that there are costs that must be incurred to reduce the conflict of interest between agents and principals namely agency costs. Principals, in this case, are of course disadvantaged because they have to incur additional costs to reduce the conflict of interest. Based on POJK regulation number 4 / POJK.03 / 2015 article 1 (2) Good corporate governance can be applied consistently to reduce agency costs and reduce perceptions of fraudulent financial reporting. It has also been proven empirically that the implementation of GCG has consistently been able to reduce fraud ( In'airat, 2015 and Kwatingtyas, 2017). It was concluded that the lower the pressure, the perception of fraudulent financial reporting would be lower, especially in companies with high good corporate governance. The hypothesis that can be described based on the above explanation is as follows:

H6: GCG weakens the positive effect of pressure on perceptions of fraudulent financial reporting

Inconsistencies that occur in previous studies encourage researchers to enter the moderating variable, namely good corporate governance. The researcher suspects that there are variables that interact with the effect of opportunity on perceptions of financial reporting fraud. Jensen \& Meckling (1976), explained that there are costs that must be incurred to reduce the conflict of interest between agents and principals namely agency costs. Principals, in this case, are of course disadvantaged because they have to incur additional costs to reduce the conflict of interest. POJK number 4 / POJK.03 / 2015 article 1 (2) concerning risk management and internal control systems explains that the implementation of consistent GCG is able to improve the supervision system and reduce opportunities for fraud. It has also been proven empirically that the implementation of GCG has consistently been able to reduce fraud ( In'airat, 2015 and Kwatingtyas, 2017). It was concluded that the lower the opportunity, the perception of financial reporting fraud would be lower, especially in companies with high good corporate governance. The hypothesis that can be described based on the above explanation is as follows:

H7: GCG weakens the positive effect of opportunity on perceptions of fraudulent financial reporting

Inconsistencies that occur in previous studies encourage researchers to enter the moderating variable, namely good corporate governance. The researcher suspects that there are variables that interact with the effect of rationalization on perceptions of financial reporting fraud. Jensen \& Meckling (1976), explained that there are costs that must be incurred to reduce the conflict of interest between agents and principals namely agency costs. Principals, in this case, are of 
course disadvantaged because they have to incur additional costs to reduce the conflict of interest. POJK number 4 / POJK.03 / 2015 article 1 (2) explains that GCG can be applied consistently to reduce agency costs and reduce perceptions of fraudulent financial reporting. It has also been proven empirically that the implementation of GCG has consistently been able to reduce fraud (In'airat, 2015 and Kwatingtyas, 2017). It was concluded that the lower the rationalization, the lower the perception of fraudulent financial reporting, especially in companies with high good corporate governance. The hypothesis that can be described based on the above explanation is as follows:

H8: GCG weakens the positive effect of rationalization on the perception of fraudulent financial reporting

Inconsistencies that occur in previous studies encourage researchers to enter the moderating variable, namely good corporate governance. The researcher suspects that there are variables that interact with the effect of competence on perceptions of financial reporting fraud. Jensen \& Meckling (1976), explained that there are costs that must be incurred to reduce the conflict of interest between agents and principals namely agency costs. Principals, in this case, are of course disadvantaged because they have to incur additional costs to reduce the conflict of interest. POJK number 4 / POJK.03 / 2015 article 1 (2) explains that GCG can be applied consistently to reduce agency costs and reduce perceptions of fraudulent financial reporting. It has also been proven empirically that the implementation of GCG has consistently been able to reduce fraud (In'airat, 2015 and Kwatingtyas, 2017). It was concluded that the lower the competence, the perception of fraudulent financial reporting will be lower, especially in companies with high good corporate governance. The hypothesis that can be described based on the above explanation is as follows:

H9: GCG weakens the positive effect of competence on perceptions of fraudulent financial reporting

The inconsistencies that occurred in previous studies encourage researchers to enter the moderating variable, namely good corporate governance. The researcher suspects that there are variables that interact with the influence of arrogance on the perception of financial reporting fraud. Principals, in this case, need to spend agency costs to control the arrogant nature contained in the agent. Agency costs incurred certainly hurt the principal because there are additional costs that need to be incurred. POJK number 4 / POJK.03 / 2015 article 1 (2) explains that GCG can be applied consistently to reduce these costs and increase internal supervision. Empirical evidence has also proven that when companies consistently implement GCG, they will be able to reduce fraud (In'airat, 2015 and Kwatingtyas, 2017). It was concluded that the lower the arrogance, the perception of fraudulent financial reporting would be lower, especially in companies with high good corporate governance. The hypothesis that can be described based on the above explanation is as follows:

H10: GCG weakens the positive influence of arrogance on perceptions of fraudulent financial reporting

\section{Materials and Methods}

The study was conducted on all employees who held directors and commissioner positions at PT BPR Bali Province. The reason for choosing the location was due to two cases that occurred in BPR KS BAS and BPR Legian whose business licenses were revoked due to the arrogance of the directors. ACFE (2018), also explained that the results of an analysis of 2,690 cases of work fraud in 125 countries worldwide from the period January 2016-October 2017 found that the banking and financial services sector had the highest number of cases from the 24 other sectors studied.

The object of research is the problem under study. The object of research is limited to the perception of fraudulent financial reporting that is detected through indicators of the pentagon fraud theory with good corporate governance as a moderator.

Researchers used all employees who held directors and commissioner positions at PT BPR Bali province to become the study population. PT BPR provinces registered until June 2019 there are 134 companies (OJK, 2019). The population-based on data from the OJK and the Indonesian People's Credit Bank Association (PERBARINDO) is 516 employees from 134 registered rural banks. The sampling technique used is nonprobability sampling with the saturated sampling method. Thus, the number of samples used in this study is 225 . The tolerance limit for sampling error is set at $5 \%$ because the value is closest to the total population of the study. The data analysis technique used in this study uses moderated regression analysis (MRA).

Sawaka K., I. G. N. H., \& Ramantha, I. W. (2020). Fraud pentagon theory in detecting financial perception of financial reporting with good corporate governance as moderator variable. International Research Journal of Management, IT and Social Sciences, 7(1), 84-94. https://doi.org/10.21744/irjmis.v7n1.824 


\section{Results and Discussions}

Researchers use Moderated Regression Analysis (MRA) which contains the interaction between multiplications of two or more dependent variables. The test results can be seen in Table 1.

Table 1

MRA testing result

\begin{tabular}{|c|c|c|c|c|c|}
\hline \multirow[t]{2}{*}{ Model } & \multicolumn{2}{|c|}{$\begin{array}{l}\text { Unstandardized } \\
\text { Coefficients }\end{array}$} & \multirow{2}{*}{$\begin{array}{l}\text { Standardized } \\
\text { Coefficients } \\
\text { Beta } \\
\end{array}$} & \multirow[t]{2}{*}{$\mathrm{t}$} & \multirow[t]{2}{*}{ Sig } \\
\hline & B & Std. Error & & & \\
\hline (Constant) & 1,886 & 24,642 & & 0,077 & 0,939 \\
\hline TK & $-2,321$ & 0,881 & $-2,731$ & $-2,635$ & $* * 0,009$ \\
\hline PL & 1,564 & 0,768 & 1,728 & 2,037 & $* 0,043$ \\
\hline RS & 5,589 & 1,494 & 5,924 & 3,742 & $* 0,000$ \\
\hline KM & $-1,279$ & 1,353 & $-1,402$ & $-0,945$ & 0,346 \\
\hline AR & $-0,368$ & 0,558 & $-0,728$ & $-0,659$ & 0,511 \\
\hline GCG & 0,100 & 0,365 & 0,278 & 0,275 & 0,784 \\
\hline $\mathrm{TK} * \mathrm{GCG}$ & 0,034 & 0,013 & 3,598 & 2,599 & $* * 0,010$ \\
\hline $\mathrm{PL} * \mathrm{GCG}$ & $-0,023$ & 0,011 & $-1,905$ & $-2,040$ & $* 0,043$ \\
\hline $\mathrm{RS} * \mathrm{GCG}$ & $-0,083$ & 0,022 & $-7,359$ & $-3,747$ & $* 0,000$ \\
\hline $\mathrm{KM} * \mathrm{GCG}$ & 0,020 & 0,020 & 1,812 & 0,999 & 0,319 \\
\hline $\mathrm{AR} * \mathrm{GCG}$ & 0,008 & 0,008 & 1,434 & 0,976 & 0,330 \\
\hline RSquare & & & 0,262 & & \\
\hline Adj R Square & & & 0,221 & & \\
\hline Fhit & & & 6,304 & & \\
\hline Sig.F & & & 0,000 & & \\
\hline
\end{tabular}

Secondary Data, 2019

p.s:

*: Significant and appropriate with the hypothesis of the researcher.

**: Significant but inappropriate with the hypothesis of the researcher.

Information:

$\mathrm{TK}=$ Pressure

$\mathrm{PL}=$ Opportunity

$\mathrm{RS}=$ Rationalization

$\mathrm{KM}=$ Competence

$\mathrm{AR}=$ Arrogance

GCG = Good corporate governance

$\beta 1-5=$ Coefficient of independent variable regression

$\beta 6=$ Regression coefficient of moderating variable

$\beta 7-11=$ Coefficient of interaction between variables

$\mathrm{TK} * \mathrm{GCG}=$ Interaction between pressure and good corporate governance

$\mathrm{PL} * \mathrm{GCG}=$ Interaction between opportunity and good corporate governance

$\mathrm{RS} * \mathrm{GCG}=$ Interaction between rationalization with good corporate governance

$\mathrm{KM} * \mathrm{GCG}=$ Interaction between competencies and good corporate governance

$\mathrm{AR} * \mathrm{GCG}=$ Interaction between arrogance and good corporate governance

F test

F statistical test basically shows how far the influence of all independent variables simultaneously in explaining the variation of the dependent variable (Ghozali, 2016). The F test can be known by looking at the results of the regression which is done by comparing the level of significance of $F$ with a $5 \%$ confidence level $(\alpha=0.05)($ Ghozali, 2016). Table 5.14 shows that the calculated $\mathrm{F}$ value is 6.304 with a significance level of 0.000 less than $\alpha=0.05$, therefore the model is suitable to be used to prove the hypothesis formed. 
Test the coefficient of determination $\left(R^{2}\right)$

The coefficient of determination $\left(\mathrm{R}^{2}\right)$ basically measures how far the model's ability to explain the variation of the dependent variable (Ghozali, 2016). Table 1. shows that the adjusted R2 value of 0.221 means that $22.1 \%$ of the variable perception of financial reporting fraud can be explained by the pressure, opportunity, rationality, competence, arrogance and GCG variables that moderate all indicators of the pentagon theory fraud, the remaining $77.9 \%$ is influenced by other variables not included in the model.

\section{Partial significance test ( $t$-test) \\ The Effect of pressure on perceptions of financial reporting fraud}

The MRA test results show that the pressure variable has a regression coefficient of $-2,321$ and a significance value of 0.00 . These results indicate that the hypothesis is rejected. This means that when individuals in this case directors and commissioners in BPR when under pressure then the perception of fraud in financial reporting will not arise due to fear of the risks that will be faced. Theoretically also explained by Einshardt (1989), who explained that to meet the interests of individuals, avoiding risk (risk-averse) is a natural thing when individuals get pressure. These results are also supported by several previous researchers who found there were negative effects of pressures on fraudulent financial reporting such as Setiawati \& Baningrum (2018); Nindito (2018); Husmawati et al. (2017); and Prasmaulida (2016), with theoretical conclusions as revealed Einshardt (1989).

\section{The Effect of opportunity on perceptions of financial reporting fraud}

MRA test results indicate that the opportunity variable has a regression coefficient of 1.569 and a significance value of 0.04 . These results indicate that the hypothesis is accepted. This is in line with the fraud triangle theory explained by Cressey (1953), that the opportunity indicator in the theory influences fraud. Individuals, in this case, are directors and commissioners at BPR when they get the chance, it will bring up the perception of fraud and more specifically the perception of fraud in financial reporting. It is also in line with the explanation of agency theory which states that to maximize individual utility can be done by utilizing opportunities to commit fraud. The results are also similar to some previous studies which explain the positive influence between opportunities and fraud such as Kusuma et al. (2017); Muhsin \& Nurkhin (2018); and Rukmana (2018), with theoretical conclusions such as agency theory and fraud triangle theory.

\section{The effect of rationality on the perception of fraudulent financial reporting}

The MRA test results show that the rationality variable has a regression coefficient of 5.589 and a significance value of 0.00 . These results indicate that the hypothesis is accepted. These results indicate that there is a positive effect of rationality on the perception of fraudulent financial reporting. It is also in line with the explanation of fraud triangle theory explained by Cressey (1953), which explains that the indicator of rationality influences fraud. Agency theory also explains that when individuals want to maximize their utility by fraudulent financial reporting, actions of rationality can help individuals to cover these opportunistic perceptions. These results are also supported by several previous researchers who explain that rationality has a positive effect on fraudulent financial reporting (Oka et al. 2018; Aprilla et al. 2018; and Siddiq, 2017).

\section{The Effect of competence on perceptions of financial reporting fraud}

The MRA test results show that the competency variable has a regression coefficient of -1.279 and a significance value of 0.34 . These results indicate that the hypothesis is rejected. This is not in accordance with additional indicators from Horwarth (2011), in the explanation of fraud pentagon theory. Descriptive statistics explain that the average respondent was indicated to have competence. The conclusion is that when individuals in this case directors and commissioners have the competence (ability), the individual actually wants to show maximum performance for certain motivations as well as bonuses in terms of positive accounting theory (Watts \& Zimmeraman, 1986). It is also in accordance with the questionnaire indicated that the highest average answer on the maximum freedom indicator in doing work, which indicates that the individual will be easier to achieve motivation. Other research also supports this, that when individuals have the ability or get a position then the individual is actually more motivated to want to get more bonuses

Sawaka K., I. G. N. H., \& Ramantha, I. W. (2020). Fraud pentagon theory in detecting financial perception of financial reporting with good corporate governance as moderator variable. International Research Journal of Management, IT and Social Sciences, 7(1), 84-94. https://doi.org/10.21744/irjmis.v7n1.824 
by maximizing performance and improving performance that was previously considered less than optimal (Aprilia, 2017; Quraini \& Rimawati, 2018; and Junardi et al., 2018).

\section{The Effect of arrogance on perceptions of financial reporting fraud}

The MRA test results show that the arrogance variable has a regression coefficient of -0.386 and a significance value of 0.51 . These results indicate that the hypothesis is rejected. Arrogance in explaining pentagon theory fraud has not been proven to be able to influence fraud. Descriptive statistics explain that there is an indication of arrogance in the sample of researchers, but this does not merely lead to perceptions of fraudulent financial reporting. This also corresponds to the highest average answer on the questionnaire indicated that it is in the approval-seeking indicator, which indicates that the arrogance of the research respondents is limited to the arrogant attitude that other individuals want to acknowledge and not the arrogant nature that can lead to perceptions of fraud.

Danuta (2017), explains that when an individual has an arrogance but does not have the competence then cheating will be difficult due to the lack of ability to commit fraud. Previous researchers also explained that arrogance did not affect financial reporting fraud because the measurement of these variables was quite difficult and could not only be seen by the number of images in company documents (Setiawati \& Baningrum, 2018; Junardi et al. 2018; and Aprilia, 2017).

The ability of good corporate governance to moderate the effects of pressure on perceptions of fraudulent financial reporting

The MRA test results showed that the pressure interaction with GCG had a coefficient value of 0.034 with a significance of 0.01 . The direct effect of the pressure variable has a coefficient of $-2,321$, meaning that GCG weakens the negative effect of pressure on perceptions of fraudulent financial reporting. These results indicate that the hypothesis was rejected. Weakening the negative influence means that the consistent application of GCG in BPR is able to reduce and prevent the perception of fraudulent financial reporting arising from other factors felt by the individual. The consistent implementation of GCG based on POJK regulation number 4 / POJK.03 / 2015 can help BPRs in handling all forms of conflict of interest such as conflicts of interest and also be able to increase the transparency of financial and non-financial conditions. It is also in accordance with agency theory which explains that when there is a conflict of interest in a company, the agency costs in a company will increase, and to reduce these costs, GCG can be applied consistently. These results have also been consistent with some previous researchers who have proven that the consistent application of GCG is able to reduce fraud (Luthan \& Satria, 2016; Saputra, 2017; and Pamungkas et al., 2018).

The ability of good corporate governance to moderate the effect of opportunities on perceptions of fraudulent financial reporting

The MRA test results show that the opportunity interaction variable with GCG has a coefficient value of -0.023 with a significance of 0.04 . The direct effect of opportunity variable has a coefficient value of 1.569 , meaning that GCG weakens the positive effect of opportunity on perceptions of financial reporting fraud. These results indicate that the hypothesis is accepted. Weakening the positive influence means that the consistent application of GCG in BPR is able to reduce and prevent the perception of fraudulent financial reporting arising from opportunities owned by individuals. These results are also in accordance with agency theory where when there is a conflict of interest, GCG is able to reduce agency costs arising from the conflict of interest. These results have also been consistent with some previous researchers who have proven that the consistent application of GCG is able to reduce fraud (Luthan \& Satria, 2016; Saputra, 2017; and Pamungkas et al., 2018).

The ability of good corporate governance to moderate the effect of rationalization on the perception of fraudulent financial reporting

The MRA test results show that the interaction between rationality and GCG has a coefficient of -0.083 with a significance of 0.00 . The direct effect of the pressure variable has a coefficient of 5.589, meaning that GCG weakens the positive effect of rationality on the perception of financial reporting fraud. These results indicate that the hypothesis 
is accepted. Weakening the positive influence means that the consistent application of GCG is able to reduce and prevent the perception of fraudulent financial reporting arising from individual rationalizations. These results are also in accordance with agency theory where when there is a conflict of interest, GCG is able to reduce agency costs arising from the conflict of interest. These results are also consistent with some previous researchers who have proven that the consistent application of GCG is able to reduce fraud (Luthan \& Satria, 2016; Saputra, 2017; and Pamungkas et al., 2018).

The ability of good corporate governance to moderate the effect of competence on perceptions of financial reporting fraud

The MRA test results show that the ability interaction variable with GCG has a coefficient value of 0.020 with a significance of 0.31 . This means that GCG does not moderate the effect of ability on perceptions of financial reporting fraud. These results indicate that the hypothesis was rejected. Inconsistent with some of the previous researchers who explained that the application of GCG is able to reduce financial reporting fraud (Luthan \& Satria, 2016; Saputra, 2017; and Pamungkas et al., 2018). GCG does not moderate the influence of ability on the perception of fraud meaning that the competencies of BPR directors and commissioners are used to maximize performance in order to achieve maximum bonuses, and are not solely used to practice the perception of fraudulent financial reporting. Therefore, the function of GCG, in this case, is only used as a guide for the individual to help maximize their performance. These results support the research of Astuti et al. (2019), which explains that the average implementation of Islamic banking corporate governance is good, but not enough to prevent fraud. That is because the sharia supervisory board is more focused on product supervision whether it is in accordance with sharia principles.

The ability of good corporate governance to balance the influence of arrogance on perceptions of financial reporting fraud

The MRA test results show that the ability interaction variable with GCG has a coefficient value of 0.008 with a significance of 0.33 . This means that GCG does not moderate the effect of arrogance on perceptions of financial reporting fraud. These results indicate that the hypothesis was rejected. GCG does not moderate means that the application of GCG in BPR will be difficult to reduce or even unable to prevent the perception of fraudulent financial reporting arising from the nature of arrogance because individuals who have an arrogance nature will assume that if there are rules in the company then they will feel that internal control does not apply to itself as a result of arrogance arising from individual positions/positions. These results are in accordance with Astuti et al. (2019), which explains that the application of corporate governance has not been able to prevent fraud. Ismiyanti \& Prastichia (2015), also explained that corporate governance consisting of independent commissioners, commissioners' meetings, length of service tenure of directors, largest share ownership and type of auditor did not influence financial statement fraud.

\section{Conclusion}

This research can provide theoretical and practical benefits. Theoretically, it can be used as a reference for other researchers who will conduct further research. Practically, this research can be considered by companies in terms of GCG. BPR, in this case, is obliged to apply GCG consistently to help improve individual performance and reduce perceptions of financial reporting fraud arising from several pentagon theory fraud indicators.

The pressure variable has a negative effect on the perception of financial reporting fraud. Individuals in this case directors and commissioners in BPR when under pressure then the perception of fraud in financial reporting will not arise due to fear of the risks to be faced. This is in accordance with the explanation of Einshardt (1989), who explained that to meet the interests of individuals, avoiding risk (risk-averse) is a natural thing when individuals get pressure.

The opportunity variable has a positive effect on the perception of financial reporting fraud. Individuals, when they get the opportunity, will bring up the perception of fraud and more specifically the perception of fraud in financial reporting. It is also in line with the explanation of agency theory which states that to maximize individual utility can be done by utilizing opportunities to commit fraud.

Variable rationality has a positive effect on perceptions of financial reporting fraud. These results are consistent with agency theory which explains that when individuals want to maximize their utility by committing financial reporting fraud, acts of rationality can help individuals to mask these opportunistic perceptions.

Sawaka K., I. G. N. H., \& Ramantha, I. W. (2020). Fraud pentagon theory in detecting financial perception of financial reporting with good corporate governance as moderator variable. International Research Journal of Management, IT and Social Sciences, 7(1), 84-94. https://doi.org/10.21744/irjmis.v7n1.824 
The competency variable does not affect the perception of financial reporting fraud. These results explain that when individuals in this case directors and commissioners have the competence (ability or position), the individual actually wants to show maximum performance for certain motivations as well as bonuses in the case of positive accounting theory, instead of giving rise to opportunistic perceptions such as fraudulent financial reporting.

The arrogance variable does not affect the perception of financial reporting fraud. These results explain that the nature of arrogance that exists in individuals is not merely able to bring up the perception of financial reporting fraud. Danuta (2017), explains that when an individual has an arrogance but does not have the competence then cheating will be difficult due to the lack of ability within the individual to commit fraud.

GCG weakens the negative influence of pressure on perceptions of fraudulent financial reporting. Weakening the negative influence means that the consistent application of GCG in BPR is able to reduce and prevent the perception of fraudulent financial reporting arising from other factors felt by the individual. Regression test results on the interaction of these variables indicate that GCG is a type of pure moderation.

GCG weakens the positive influence of opportunity on perceptions of fraudulent financial reporting. Weakening the positive influence means that the consistent application of GCG in BPR is able to reduce and prevent the perception of fraudulent financial reporting arising from opportunities owned by individuals. Regression test results on the interaction of these variables indicate that GCG is a type of pure moderation.

GCG weakens the positive effect of rationality on perceptions of fraudulent financial reporting. Weakening the positive influence means that the consistent application of GCG is able to reduce and prevent the perception of fraudulent financial reporting arising from individual rationalizations. These results are also in accordance with agency theory where when there is a conflict of interest, GCG is able to reduce agency costs arising from the conflict of interest. Regression test results on the interaction of these variables indicate that GCG is a type of pure moderation.

GCG does not moderate the effect of competence on perceptions of fraudulent financial reporting. GCG does not moderate the influence of ability on the perception of fraud meaning that the competencies of BPR directors and commissioners are used to maximize performance in order to achieve maximum bonuses, and are not solely used to practice the perception of fraudulent financial reporting. Therefore, the function of GCG, in this case, is only used as a guide for the individual to help maximize their performance. Regression test results on the interaction of these variables indicate that GCG is a type of potential moderation.

GCG does not moderate the effect of arrogance on perceptions of financial reporting fraud. GCG does not moderate means that the application of GCG in BPR will be difficult to reduce or even unable to prevent the perception of fraudulent financial reporting arising from the nature of arrogance because individuals who have an arrogance nature will assume that if there are rules in the company then they will feel that internal control does not apply to itself as a result of arrogance arising from individual positions/positions.

\section{Conflict of interest statement}

The authors declared that they have no competing interests.

\section{Statement of authorship}

The authors have a responsibility for the conception and design of the study. The authors have approved the final article.

\section{Acknowledgments}

The authors would like to thank the reviewer for their consideration of the further process of the present paper. Thanks to the editor of IRJMIS for the valuable support, time as well as advice. 


\section{References}

Akbar, T. (2017). The determination of fraudulent financial reporting causes by using pentagon theory on manufacturing companies in indonesia. International Journal of Business, Economics and Law, 14(5), $106-133$.

Aprilia, A. (2017). Analisis pengaruh fraud pentagon terhadap kecurangan laporan keuangan menggunakan beneish model pada perusahaan yang menerapkan asean corporate governance scorecard. Jurnal ASET (Akuntansi Riset), 9(1), 101-132.

Aprilla, Vivi Rizkiana., Adri Satriawan Surya, R., \& Zarefar, Arumega. (2018). Pengaruh Financial Stability, External Pressure, Ineffective Monitoring, Change in Auditor, Change in Director dan Frequent Number of CEO's Picture terhadap Financial Statement Fraud dalam Perspektif Fraud Pentagon (Studi Empiris pada Perusahaan Manufaktur yang terdaftar di BEI 2011-2016). JOM FEB, 1(1), 1-15.

Association of Certified Fraud Examiners (ACFE). (2018). Report to the Nations 2018, Global Study on Occupational Fraud and Abuse - Asia Pacific Edition. United States.

Astuti, M. A., Rozali, R. D. Y., \& Cakhyaneu, A. (2019). Prevention of Fraud in Sharia Banking in Indonesia through Implementation of Sharia Corporate Governance. KnE Social Sciences, 183-202.

Bawekes, H. F., Simanjuntak, A. M., \& Daat, S. C. (2018). Pengujian Teori Fraud Pentagon Terhadap Fraudulent Financial Reporting. Jurnal Akuntansi Dan Keuangan Daerah, 13(1), 114-134.

Cressey, D. R. (1953). Other people's money; a study of the social psychology of embezzlement.

Crowe, H. (2011). The Mind Behind The Fraudsters Crime: Key Behavioral and Environmental Element.

Danuta, K. S. (2017). Crowe's Fraud Pentagon Theory dalam Pencegahan Fraud pada Proses Pengadaan melalui EProcurement. Jurnal Kajian Akuntansi, 1(2). http://dx.doi.org/10.33603/jka.v1i2.826

Ghozali, I. (2018). Aplikasi analisis multivariete dengan program IBM SPSS 23.

Husmawati, P., Septriani, Y., Rosita, I., \& Handayani, D. (2017, October). Fraud Pentagon Analysis in Assessing the Likelihood of Fraudulent Financial Statement (Study on Manufacturing Firms Listed in Bursa Efek Indonesia Period 2013-2016). In International Conference of Applied Science on Engineering, Business, Linguistics and Information Technology (pp. 45-51). ICo-ASCNITECH.

In'airat, M. (2015). The Role of Corporate Governance in Fraud Reduction-A Perception Study in the Saudi Arabia Business Environment. Journal of Accounting \& Finance (2158-3625), 15(2).

Ismiyanti, F., \& Prastichia, C. (2015). Mekanisme Corporate Governance dan Kecurangan Laporan Keuangan [Mechanisms of Corporate Governance and Financial Statement Fraud]. DeReMa (Development Research of Management): Jurnal Manajemen, 10(2), 200-226. http://dx.doi.org/10.19166/derema.v10i2.171

Jensen, M. C., \& Meckling, W. H. (1976). Theory of the firm: Managerial behavior, agency costs and ownership structure. Journal of financial economics, 3(4), 305-360. https://doi.org/10.1016/0304-405X(76)90026-X

Jensen, M. C., \& Meckling, W. H. (1976). Theory of the firm: Managerial behavior, agency costs and ownership structure. Journal of financial economics, 3(4), 305-360. https://doi.org/10.1016/0304-405X(76)90026-X

Junardi., Nella, Yantiana., \& Khristina, Yunita. (2018). Analisis Pengaruh Fraud Pentagon terhadap fraudulent financial reporting dengan Menggunakan Model Altman (Studi Empiris pada Perusahaan Sektor Keuangan dan Perbankan di Indonesia. Tesis. Universitas Tanjungpura.

Kathleen, M. E. (1989). Agency theory: an assessment and review. The academy of management review, 14(1), 57-74.

Kurnia, Aidil Adherian., \& Anis, Idrianita. (2017). Analisis Fraud Pentagon dalam Mendeteksi Kecurangan Laporan Keuangan Dengan Menggunakan Fraud Score Model. Simposium Nasional Akuntansi XX. Jember.

Kusuma, I., Perdana, H. D., \& Suranta, S. (2017). Fraudulent financial reporting by district/municipal government in indonesia1. Asia Pacific Fraud Journal, 2(1), 27-48. http://dx.doi.org/10.21532/apfj.001.17.02.01.03

Kwatingtyas, L. P. A. (2017). Pengaruh Pengendalian Internal dan Manajemen Risiko Pada Good Corporate Governance Serta Implikasinya Dalam Pencegahan Fraud (Doctoral dissertation, Tesis).

Luthan, E., \& Satria, I. (2016). The Effect of Good Corporate Governance Mechanism to Earnings Management Before and After IFRS Convergence. Procedia-Social and Behavioral Sciences, 219, 465-471. https://doi.org/10.1016/j.sbspro.2016.05.021

Nindito, M. (2018). Financial Statement Fraud: Perspective of the Pentagon Fraud Model in Indonesia. Academy of Accounting and Financial Studies Journal.

Nurkhin, A. (2018). What Determinants of Academic Fraud Behavior? From Fraud Triangle to Fraud Pentagon Perspective. KnE Social Sciences, 154-167. https://doi.org/10.18502/kss.v3i10.3126

Otoritas Jasa Keuangan (OJK). (2019). Daftar Alamat Kantor Pusat BPR 042019. April. OJK. Indonesia.

Pamungkas, I. D., Ghozali, I., Achmad, T., Khaddafi, M., \& Hidayah, R. (2018). Corporate Governance Mechanisms in Preventing Accounting Fraud: A Study of Fraud Pentagon Model. Journal of Applied Economic Sciences, 13(2).

Sawaka K., I. G. N. H., \& Ramantha, I. W. (2020). Fraud pentagon theory in detecting financial perception of financial reporting with good corporate governance as moderator variable. International Research Journal of Management, IT and Social Sciences, 7(1), 84-94. https://doi.org/10.21744/irjmis.v7n1.824 
Perhimpunan Bank Perkreditan Rakyat Indonesia. (2019). Daftar Anggota Perbarindo Se-Bali. September. PERBARINDO Denpasar Utara. Denpasar.

Pramana, Y., Suprasto, H. B., Putri, I. G. A. M. D., \& Budiasih, I. G. A. N. (2019). Fraud factors of financial statements on construction industry in Indonesia stock exchange. International Journal of Social Sciences and Humanities, 3(2), 187-196. https://doi.org/10.29332/ijssh.v3n2.313

Prasmaulida, S. (2016). Financial statement fraud detection using perspective of fraud triangle adopted by SAS No. 99. Asia Pacific Fraud Journal, 1(2), 317-335. http://dx.doi.org/10.21532/apfj.001.16.01.02.24

Puspitha, M. Y., \& Yasa, G. W. (2018). Fraud pentagon analysis in detecting fraudulent financial reporting (study on Indonesian capital market). International Journal of Sciences: Basic and Applied Research, 42(5), 93-109.

Quraini, F., \& Rimawati, Y. (2018). Determinan Fraudulent Financial Reporting Using Fraud Pentagon Analysis. Journal of Auditing, Finance, and Forensic Accounting, 6(2), 105-114.

Rengganis, R. M. Y. D., Sari, M. M. R., Budiasih, I. G. A. N., Wirajaya, I. G. A., \& Suprasto, H. B. (2019). The fraud diamond: element in detecting financial statement of fraud. International research journal of management, IT and social sciences, 6(3), 1-10. https://doi.org/10.21744/irjmis.v6n3.621

Rukmana, H. S. (2018). Pentagon Fraud Affect on Financial Statement Fraud and Firm Value Evidence in Indonesia. South East Asia Journal of Contemporary Business, Economics and Law, 16(5).

Sanjaya Adi Putra, G., \& Dwirandra, A. A. N. B. (2019). The effect of auditor experience, type of personality and fraud auditing training on auditors ability in fraud detecting with professional skepticism as a mediation variable. International Research Journal of Management, IT and Social Sciences, 6(2), 31-43. https://doi.org/10.21744/irjmis.v6n2.604

Saputra, A. (2017). Pengaruh Sistem Internal Kontrol, Audit Internal dan Penerapan Good Corporate Governance Terhadap Kecurangan (Fraud) Perbankan (Studi Kasus pada Bank Syariah Anak Perusahaan BUMN di Medan). Owner, l(1).

Septriani, Y., \& Handayani, D. (2018). Mendeteksi Kecurangan Laporan Keuangan dengan Analisis Fraud Pentagon. Jurnal Akuntansi Keuangan dan Bisnis, 11(1), 11-23.

Setiawati, E., \& Baningrum, R. M. (2018). Deteksi Fraudulent Financial Reporting Menggunakan Analisis Fraud Pentagon: Studi Kasus pada Perusahaan Manufaktur yang Listed di BEI Tahun 2014-2016. Riset Akuntansi Dan Keuangan Indonesia, 3(2), 91-106. https://doi.org/10.23917/reaksi.v3i2.6645

Siddiq, F. R., Achyani, F., \& Zulfikar, Z. (2017). Fraud Pentagon dalam Mendeteksi Financial Statement Fraud.

Tessa, C., \& Harto, P. (2016). Fraudulent financial reporting: pentagon testing fraud theory in financial sector and banking in Indonesia. In National Symposium on Accounting XIX. Lampung: National Symposium on Accounting XIX. Available at: http://lib. ibs. ac. id/materi/Prosiding/SNA\% 20XIX (Vol. 20, p. 19).

Utama, I. G. P. O. S., Ramantha, I. W., \& Badera, I. D. N. (2018). Analisis faktor-faktor dalam perspektif fraud triangle sebagai prediktor fraudulent financial reporting. E-Jurnal Ekonomi dan Bisnis Universitas Udayana, 251-278. https://doi.org/10.24843/EEB.2018.v07.i01.p09

Watts, R. L., \& Zimmerman, J. L. (1986). Positive accounting theory.

Wolfe, D. T., \& Hermanson, D. R. (2004). The fraud diamond: Considering the four elements of fraud.

Zamzam, I., Mahdi, S. A., \& Ansar, R. (2017). Pengaruh Diamond Fraud dan Tingkat Religiuitas terhadap Kecurangan Akademik (Studi pada Mahasiswa S-1 di Lingkungan Perguruan Tinggi Se Kota Ternate). https://doi.org/10.24252/.v3i2.4546 